\title{
Bulgarian Traditional Folklore Celebrating Food and Sustainability
}

\author{
Diana Bogueva, The University of Sydney, Australia \& Curtin University, Australia \\ Dora Marinova, Curtin University, Australia \\ (iD https://orcid.org/0000-0001-5125-8878 \\ Vladislav Todorov, University of Forestry, Bulgaria
}

\begin{abstract}
Being an integral part of the past cultural heritage, the traditional Bulgarian folklore festivals, carnivals, and celebrations are continuing to promote sustainable practices that venerate and respect nature. The article focusses specifically on celebrations related to food and plant growing. It reviews the intangible cultural heritage of the Bulgarian folklore, including traditions whose roots originated from pagan rituals but continue to be observed now. A description of the Kukeri carnival, Trifon Zarezan, Baba Marta, Peperuda (Butterfly), Rose Festival, Nestinari dancing rituals, and Enyovden are provided within a sustainability context. A common feature between these celebrations is the respect for nature and its healing capacity with people being perceived as part of the natural world. These traditional folklore festivities have survived the test of time with very little commercialisation. Food plays a major role in them, but most importantly, they help maintain the community spirit and social bonding.
\end{abstract}

\section{KEYWORDS}

Baba Marta, Bulgaria, Kukeri, Nestinari, Orthodox, Pegan, Peperuda, Rose Festival, Trifon Zarezan

\section{INTRODUCTION}

Festivals, carnivals and celebrations are an essential part of the Bulgarian folklore traditions and folk calendar. They represent a mixture between old pagan traditions, Christian and other religious elements. The Bulgarian folklore culture is by all means a living phenomenon that is constantly growing and evolving in the mind, psyche and practices of the current generation. It is passed from one generation to another and is at the core of the cultural sustainability of this small Balkan nation. 
Bulgarian history goes back to the establishment of the state in the year 681 when two tribes - a sedimentary slovonic tribe with tall blue-eyed and blonde people engaged mainly with agriculture, the South Slavs, and a horse-riding semi-nomadic darker skinned black-eyed warrior tribe who arrived from the Eurasian steppe, the Bulgars, established a union on the Balkan Peninsula. They created a pact of peace and mutual support. This combination of Slavic and Bulgar blood continues to run in the veins of all Bulgarian families nowadays. It helped the nation survive two centuries of Byzantine (1018-1185) and five centuries of Ottoman rule (1396-1878).

In 870 Bulgaria adopted Chistianity and established an independent national church headed by an archbishop. This new faith was adopted alongside the already existing numerous paganistic beliefs and rituals going back to the Tracians, the first people to leave their mark on the Balkan Peninsula. The paganistic tradition extended throughout the centuries of the Persian sway, Celts and Romans and was also present in the beliefs of the original Slavs and Bulgars (Topalov \& Nikolaeva, 2006). For example, the Bulgars believed in the legend that their ancestor was Avitohol - a man raised by a deer who lived for 300 years. Avitohol was also the one who directed the tribe to take the road towards the Balkans (BNT, 2019). Many of the pagan traditions are still alive today on their own or intertwined with the beliefs and rituals of the Bulgarian Orthodox Church. With most pagan religions being polytheistic (Cameron, 2011), characteristic about Bulgarian paganism is similarly in its tendency to believe and worship many gods. Another essential feature is the veneration of nature (Harvey, 2010) and the celebration of its seasons that particularly impact food production.

Folk customs, dances, songs, stories, proverbs and other folkloric traditions occupy a prominent place in people's communal and private lives. Many of them originate from paganistic times and are directly related to growing and consuming food. They also introduce cultural sustainability and stability in the social reality, keep the Bulgarian nation united and maintain its culture. Festive gatherings, folklore festivals, carnivals and celebrations contribute to traditional sustainability and are most strongly safeguarded within the family and social environment. These traditions are part of the intangible cultural heritage preserved and transmitted by our ansestors passed onto us to keep, maintain and enrich with new wisdom. The ancient, old and current Bulgarians have followed and continue to adhere to the same calendar of festivities, rituals and events. They do this not only because of their own spirituality and values but also because this folk culture is in harmony with the cycles of the natural world. As time goes by, these traditions are being interpreted and re-interpreted by each generation keeping them alive. They also hold the key to a more sustainable society and represent a treasure house of human experience in interacting with the forces of nature.

In this article, we particularly explore the pagan folk traditions linked to food consumption arguing that they are closely related with the present sustainability priorities. Furthermore, these folklore celebrations help maintain social cohesion and contribute towards spiritual and physical well-being. The analysis is based on secondary sources as well as on the personal knowledge and obserations of the authors who are Bulgarian. We first provide a brief overview of traditional folk culture in contemporary Bulgaria and then analyse specifically food-related traditions and their contribution towards sustainability. The analysis covers traditions which have originated during and continue to be connected to pagan culture although more recent religious beliefs have given them an added meaning. Representing social and religious inclusion, they also promote sustainability related to food and broader social values.

\section{CONTEMPORARY LIFE AND TRADITIONAL FOLK CULTURE IN BULGARIA}

Bulgaria is a culturally diverse country with a rich intangible folklore heritage. Its population composition reflects the history of the place, including Ottoman rule and other population movements. As the Constitution of Bulgaria forbids people to be devided based on their culture, race or ethnicity (NSI, 2010), the official statistics of the country do not collect data nor provide estimates about the ethnic background of the Bulgarian population. Such information is collected during the census 
enumerations conducted every 10 years. The latest 2011 Census of Population and Housing estimates show that $77 \%$ of the country's 7 million population was of Bulgarian background with the main ethnic groups being Turkish (8\%), Roma (4.4\%) and smaller representation of Russians, Armenians and Vlachs while $10 \%$ of people did not declare their ethnicity (CIA, 2019). All ethnic groups adhere to different customary traditions and religions, including Christian Orthodox, Muslim, Catholic, Protestant, Armenian Apostolic Orthodox, Jewish, non-religious and atheists with more than a quarter of the population (27\%) not providing specific religious affiliation (CIA, 2019).

There is evidence that many paganistic rituals are re-surfacing in modern Bulgaria with new shrines and monuments being built to commemorate and worship the country's Thracian heritage, including ancient gods and prophets, e.g. Demeter - the Greek goddess of agriculture, fertility, the harvest, sacred law and the cycle of life and death, or Orpheus - the devine Greek prophet of music, poetry and culture who used to roam the mountains of Southern Bulgaria (Trud, 2016; Topalov \& Nikolaeva, 2006). According to Bulgarian ethnologues, archeologues and anthropologists, many paganistic rituals have become entwined, intertwined and masked as Christian, such as dances, songs, symbols, walking on fire or loud noises to dispel evil spirits (Trud, 2016). The celebration of name days rather than saint days is another example where people's beliefs have overruled the Christian tradition (Nova, 2018). This interconnection between people is also manifested across religions. For example, Orthodox Bulgarians may have a kurban prayer or sacrificial rite, similar to their Muslim friends. Bulgaria is a culturally rich country where the differences have permeated the centuries of history and are now uniting rather than dividing its population.

However, as is the case around the world, globalisation in the 21 st century is contributing towards blurring the differences between ethnic groups and the disappearance of unique traditional features. Globalisation threatens cultural and national identities and people's identification with certain folklore practices, consumption of traditional food and beverages, the diversity of languages and cultures pushing them towards homogenisation. Many Bulgarian cultural events - festivals, celebrations, folk music, dance, rites and rituals together with interrelated food and culinary practices, traditional arts and skills, may be lost under the influence of modern life and globalised tastes and preferences. With this, practices which promote sustainable behaviour, such as abstaining from the consumption of animal-based foods for prolongued periods of time (Gaydurkov, 2014), folk dancing and singing in public squares or growing fruit and vegetables in the house gardens, may also vanish.

Globalisation has many negative aspects which create fear, destabilise and generate ambivalences (Beck, 1999; Rupert, 2000; Coker, 2002; Harriss-White, 2002) as well as erode the basis of local cultures - that is the mold which holds people together (Kaul, 2012). It also contributes towards establishing common universalised values. Many of these values are destructive to the natural environment. An example is consumerism which scientists predict to lead towards a global collapse (Lent, 2018).

There are however other values which if globalised can strengthen local cultures and communities. Sustainability values are an example of universal ethics that require to be disseminated through common globalised processes and the global Sustainable Development Goals aim to achieve this. Social justice, peace and human rigths are other examples (Verma, 2019, Oswald Spring, 2019). Such globalised sustainability, social justice and peace values can be informed by and are best conveyed through the local wisdom, traditional folk knowledge and practices held by different communities and nations.

Folk traditions and practices are usually preserved in the family and private life. However, they help maintain local cultures and strengthen the sense of community as well as bridge social divides. Most ethnologists agree that ethnic identity is no longer an objective characteristic, but rather reflects social practice and personal identification (Oktyabrskaya et al., 2008). According to Valchinova (1999), particularly in rural and village settings, such identification is the outcome of a collective choice based on long-lasting visible traditions. In the case of Bulgaria, if people participate in folk traditions, carnivals, festivals and celebrations, that helps them self-identify as Bulgarian, irrespective 
of their religious or ethnic background. This creates social inclusiveness and improves the relationships between people and also between them and their natural environment, be it in rural or urban areas. Many such celebrations and traditions originate from practices that are inherenty sustainable from a social and environmental perspective.

According to Bonye (2008), the traditional forms of celebration and revelry in their roots are related mainly to planting, harvesting and environmental cleansing, aimed at honouring ancestors as a way of receiving their blessings in return. They help revive, update and retell traditional knowledge and wisdom from generation to generation to be used as valuable tools for managing natural resources and for maintaining the balance between people and their biophysical environment. Traditional festivals, carnivals and other celebrations serve as important and natural avenues for promoting the rich cultural heritage of local communities (O'Suvillan \& Jackson, 2002).

Many young Bulgarians in this day and age are oriented more towards directing their lives along the perspectives offered by the European Union and other opportunities open to them in the globalised world rather than toward discovering and preserving their own cultural identities. There are limited efforts to protect, preserve and promote the Bulgarian cultural heritage, including the tangible and intangible traditions which foster sustainability values and sustainable behaviour. According to Karpodini-Dimitriadi et al. (2008, p. 2), significant international and European level work is needed "to increase social awareness of traditional cultural values to prepare people to accept them as a contribution to sustainable development".

The reminder of this paper explicitly analyses Bulgarian folk rituals and practices for sustainable food consumption and production. They emphasise cultural identity, connections to rural life, food preparation, rituals and festivities related to the change of seasons aimed at securing good fortune and fertility. Building community cohesion and identity, these food-related rituals and practices are also intertwined with religious celebrations and important stages in the course of human life from birth to family making and death.

\section{SUSTAINABILITY OF PEOPLE AND PLANT GROWING}

Maintaining food sustainability is a universal concept found in every culture. It requires a complex knowledge system of the natural world. Human societies around the world, including the Bulgarian, have gradually established such an understanding. Based on this, they have developed a wealth of experiences and explanations related to the environment in which they live. Traditional environmental knowledge encompasses a compound collection of information, interpretations and awareness that guides people in their constant interactions with the natural environment: in hunting, fishing and gathering plants for food; agriculture and animal husbandry; in their fight against diseases and injury; in naming and explaning natural phenomena and developing strategies for dealing with fluctuating environments (Nakashima et al., 2000, p.12).

Food sustainability in Bulgarian traditional wisdom is mainly connected with the fertility of the land, people's health and the rebirth of nature throughout the seasons. These notions are symbolised through many rituals and celebrations that form part of the Bulgarian traditional folklore and festivities. Although globalisation and development have put many of these traditions at a risk of disappearance, a lot of traditional knowledge, old-time values and spirituality guiding a sustainable way of living are still preserved in Bulgaria. Integral parts of the traditional often ceremonial complex of the Bulgarian culture are, among others, Kukeri, Trifon Zarezan, Baba Marta, Peperuda, the Rose Festival, Nestinari and Enyovden. These traditions are very much alive and performed in the country's regions. They all encourage social cohesion and sustainable behaviour and have withstood the challenges of time in the Bulgarian history. In these traditions, the themes of fertility are intertwined with growing food, family and nature. Below is a description of these folk celebrations in the order in which they occur throughout the calendar year. 


\section{Kukeri (between 25 December and 6 January)}

The Kukeri $^{1}$ celebration co-exists in between ritual, carnival and mascarade games. Originally celebrated around the time of the winter solstice, these processions now take place between the two Christian Orthodox Christmases - 25 December for the Bulgarian Church and 7 January for the remainder orthodox churches. The characters in the processions, that is Kukeri, wear masks and are dressed in unusual combinations of male and female outfits or are covered in goat and sheep skins, with large bells tied around their waists (Baeva \& Toncheva, 2019). Their masks can resemble animals with horns, big red noses and scary teeth (Angelova, 1967). Alternatively, the Kukeri can wear high conic hats as well as represent different creatures, such as a mystical king or queen, bride and groom, bears, horses, donkeys and many others (Baeva \& Toncheva, 2019). They dance during their procession, make loud noises to scare the bad spirits away. In the old days, the Kukeri were young unmarried men but nowadays, anybody can participate in such a procession. Their magic dances act out sowing, harvesting and other rituals symbolically preserving the natural order (Angelova, 2017). The Kukeri tradition performed in the Pernik region of Bulgaria is registered by UNESCO as part of humanity's living treasures (Baeva \& Toncheva, 2019).

Varying according to location and dialect, the Kukeri celebration has survived from pre-Christian pagan times, when the scary, monstrous multi-coloured masks were designed to chase away evil spirits, ensure the advent of spring, the revival of nature, and to entice good harvest, health, fertility and happiness (Brown, 2018). The Kukeri dances are performed in the towns and villages across Bulgaria during the times between Christmas and Lent which are considered "dirty days" before the world rejuvenates (Baeva \& Toncheva, 2019). During this time people eat animal-based food and their bodies become "dirty" (Baeva \& Toncheva, 2019). The doors between the world where we live and the unknown, open up and various creatures - demons, vampires, ghosts, werewolves and dark fairies, pass in threatening to punish the human beings. Different elements may form part of the noisy processions in terms of characters and scenes represented. The common feature is that all these mystical creatures reside on the cusp between animals and humans, women and men, those alive and who had passed away, people and demons (Baeva \& Toncheva, 2019). There is no stage, no particular organisation, instead the Kukeri assemble spontaneously and commence their processions.

According to Arnaudov, "[i]n answering the question about the origin and the initial meaning of the Kukeri rites, we need to consider the amazingly similar Greek pre-Lent carnival of our times as well as the Ancient mysteries of Dionysus" (Arnaudov, 1996, p. 554). The Kukeri performance has an esoteric significance. Some of the movements of the dancers may even be overtly sexual, considered rude and inappropriate within a different context but they maintain the basic notion of fertility. Through praying to the god of vegetation, together with the magical rite they aim to influence nature, using the energy of their phallic dances in the act of plowing and sowing, which represent the same through the direct magic phallus-plow/vagina-earth/sperm-grain links to increase fertility and food sustainability. The intense swinging of the main Kuker character is intended to represent the wheat's heavy grains, and the noisy banging of bells is envisioned to drive away the evil and disease from the forthcoming harvest.

Normally, the masks of the Kukeri have two faces which signify the good and the bad that inevitably exist in the world. Central in the symbolism of the masks is their colours. The most commonly used colour is red as a symbol of fertility, the regenerating nature, of the sun and fire, of health, happiness and a wealthy year. The other prevalent colour is black which represents the earth and its Mother Goddess, while the white colour is a symbol of water, purity, purification, light and a good beginning.

Trifon Zarezan (14 February) 
Trifon Zarezan is one of the oldest customs in the Bulgarian folk calendar. The celebration pays tribute to the vines, vineyards, wine and the new life as it is the first agricultural ritual in the new year. It ensures vitality and fruitfulness through the first pruning of the vineyards performed mainly by men in the company of women and children. The pruning is accompanied by a number of other food-related customs. One of them is the preparing of a freshly kneaded bread decorated with vines and grapes made of dough as a symbol of a fertile field. This bread is generously shared with neighbours and relatives (Panayotova, 2008). Another ritual on Trifon Zarezan is for the man of the house to take three burning coals from the fireplace which symbolise the energising and revitilising power of the fire and the sun. The coals are then used to predict which crops will produce the most abundant harvest in the new season.

There is also a belief that the more wine is drunk that day and poured on people, fruit trees, bushes and the roots and branches of the vines themselves, the better the coming harvest will be (Panayotova, 2008). The best vine-grower of the area is proclaimed to be the Vine King for the year and his head is decorated with a wreath made from the firstly prunned vine sticks. He is carried around on the shoulders of his mates or on a cart while all other people want to be blessed by him to improve the productivity of their vineyards (Panayotova, 2008; Baeva \& Toncheva, 2019).

Wine-making is an ancient tradition in Bulgaria dating back to Thracian times with vineyards considered a symbol of fertility. In Christianity, wine is also associated with the blood of Christ and St Trifon is a martyr and a healer (Baeva \& Toncheva, 2019). Many Bulgarian orthodox icons depict St Trifon with his pruning shears. The celebrations of Trifon Zarezan are very lively with songs, jokes and dances and usually terminate in the house of the Vine King who treats everybody with his wine (Baeva \& Toncheva, 2019).

The Trifon Zarezan celebrations coincide by date with with St Valentine's Day for the catholics. St Valentine's - the day of romance and romantic love between two people, only recently started to be acknowledged in Bulgaria under western influence. On the other hand, Trifon Zarezan has withstood the test of time and has been celebrated for millennia offering many opportunities for socialising, fun and joyful gatherings. It also represents a name day for all those who are named Trifon or have names associated with vine or grapes, such as Lozan and Grozdanka, as well as with joy, such as Veselka and Radka.

In addition to birthdays, Bulgarians also celebrate name days. As people's first names are publicly known, congratulations on name days are widely given, including at the workplace, while birthdays are considered private and celebrated only by invitation. Both, name days and birthdays, offer opportunities for socialising and enjoyment of tasty food with wine.

Baba Marta (1 March and throughout the month of March)

Colour symbolism is at the core of the traditional Bulgarian celebration of Baba Marta (translated as Grannie March) which is marked with a martenitsa - a small piece of adornment made from red and white yarn or threads in a variety of shapes. It is worn for health, prosperity, protection against evil people and disease from 1 March until the appearance of the first blooming tree or the arrival of the first migrating stork. People should wear only martenitsas received as a gift - a belief which encourages social interaction and communication.

Although you can easily buy martenitsas these days, many still make their own to give to relatives and friends. The custom and celebration of Baba Marta are considered a unique ancient pagan tradition in Bulgaria and on the Balkans. In Bulgaria, where its roots are traced back to Thracian times, it is practically observed by everybody (Lozanova, 2007). Baba Marta resembles the pagan Mother Goddess who gives life to nature that seems to have been asleep during the winter period (Baeva \& Toncheva, 2019). The white colour symbolises beauty, purity, innocence, joy, good and light while the red colour represents strength, blood, bravery, vitality, health, love, victory, life, courage, sun and warmth. 
Baba Marta herself is a mythical figure, a personification of nature in early spring - erratic, unpredictable and easily changing but also strong and life-giving. There are no Christian parallels to this pagan character. According to the legends, March is the only sister among the twelve siblings representing the months of the year and Baba Marta's character is associated with women's mood swings but also justice and punishment. If you anger Baba Marta, for example, by starting planting earlier, she responds with cold days and blizzards; if you make her happy, she brings sun and nice weather.

The ritual asks Baba Marta for mercy and is a simple act of purification from the winter season celebrating the spring and rotation of the natural cycle. A number of beliefs, customs, rites and prohibitions aimed at ensuring health for people and livestock, good crop and prolific fruit trees, are associated with Baba Marta. Cleaning the house, washing rugs, carpets, beddings and sanitising against fleas, snakes and lizards are also part of these spring celebrations observed by Bulgarians from all religions. Winter changing into spring is a period full of challenges that helps the transition towards health and fertility. The wearing of martenitsas is similarly included in UNESCO's list of intangible cultural heritage of humanity (UNESCO, 2017). Nowadays, a martenitsa adorns the icon of the Virgin in the Ocenovlashki Monastery built in Bulgaria in 2005.

\section{Peperuda (May)}

Peperuda (or butterfly in English) is another special ritual summoning rain in the spring and summer to assure conditions for healthy food production. It is a prayer aimed to provoke rain to provide the much-needed moisture to the crops for soil fertility, rich harvest and prosperity (Bulgarian Academy of Science, 2007, p. 66 -68). The chosen "butterfly", usually a girl 10-12 years old, is covered with greenery, most often comprising of elderflour foliage, because according to the Bulgarian beliefs, there is a lot of moisture where this plant grows. In some places, the "butterfly" is so ornate that it looks like a green bush moving through the village while people pour water over it. It waves its arms trying to shake the water off and indeed resembles the fluttering and flying of a butterfly (Baeva \& Toncheva, 2019).

The Bulgarian name of the ritual can also be associated with the pagan god Perun - the God of Thunder, and hence the link with rain. There is no set date for the ritual and each locality may celebrate it differently, but the month of May is the most common time. The selected girl can be a fatherless child as the heavenly forces are more likely to listen to the prayers of an orphan (MacDermott, 1998). People would give food - bread, banitsa, coocked beans, corn porridge, as the procession moves from home to home singing and dancing. Rain and sunshine make the connection between earth and sky and provide the necessary fertility for life. The Peperuda traditions aim to induce and secure fertility and shared prosperity (Marinov, 1994).

\section{Rose Festival (May to June)}

The Rose Festival celebrates the Bulgarian oil-bearing rose varieties, such as Rosa Damascena, grown since the $17^{\text {th }}$ century in the Valley of Roses. This valley stretches for $140 \mathrm{~km}$ between two mountain ranges sheltered by two rivers and provides excellent atmospheric conditions for these precious plant species (Paskova, 2018). For a month - from May till June, the festival takes place with roses being hand-picked from early dawn. Rose flowers are traditional symbols of rejuvenation, rebirth, love and memory. They are called "liquid gold" because of their high commercial value - a kilogram of rose oil requires 3,000 to 3,500 kg of roses to produce using a double distillation method (Rose Festival Kazanlak, 2019) and costs around A \$10,000 per kg (AFP, 2018). The aroma, longevity and sophistication of the rose oil makes it highly desirable by the most prestigious perfume houses in the world and is a precious export commodity (di Donato, 2018). 
Traditional banitsa, rose jam and rose liquer are usually served during the festivity accompanying the month-long Rose Festival. Even nowadays, each rose flower is carefully hand-picked in the old traditional way. Folk music, songs and dances form essential parts of the celebrations together with parades and carnival processions with a Rose Queen selected from the year's high school graduates (Paskova, 2018). The festival brings together local communities as well as numerous visitors from around the world who are captivated by the charm of the Bulgarian rose.

Nestinari (3 June and all year around)

Another traditional Bulgarian celebration registered in the UNESCO's list of humanity's intangible cultural heritage in 2009 is the Nestinar dance performed by nestinars (Baeva \& Toncheva, 2019). It is an ancient ecstatic and enigmatic ritual of pagan origin practised nowadays predominantly in the villages of the Strandzha Mountain located in the southeast part of Bulgaria (Georgieva, 1987). Barefoot nestinars holding the icon of St Constantine and St Helen walk on burning fire and dance over hot red coals or on the smouldering embers. The date is 3 June -St Constantine and St Helen's Day in the old calendar which is also a name day for those whose first names are associated with the meanings of the two Greek words - consistent/patient and light/torch (Petel.bg, 2016). Nestinar dances are also performed at other times throughout the year.

Nestinars, who are mainly women but men can also participate, execute an ecstatic, deep-trance, meditation dance in the darkness of the evening under the loud sound of a lyre and special drum music. Walking on fire is the supreme proof of sanctity of the dancer whose feet are not being harmed during the dance and the nestinars themselves do not feel pain due to their spiritual trance and ecstacy. This immunity to fire burns remains unexplained and is usually hereditary. The Nestinar culture is distinctively different with long periods of refraining from animal-based foods. There are also clear signs of ancient rites of sacrificial offering on fire acts, worshiping of the sun or sun-cults as part of the nestinar festivity (Karpodini-Dimitriadi et al., 2008).

The idea behind the nestinars' ritual dance is to merge their vital energy with that of the fire to ensure purification, symbolically burn and overcome every evil and through this act, secure the continuation of the good. One of the nestinars predicts the future, warns against evil, gives good or bad omens (Rousseva, 2010; Arnaudov, 1996) for prosperity, longevity, health and food sustainability. Although the main skill of the nestinars is to dance barefoot on embers, some also possess healing abilities and can cure sick children (Baeva \& Toncheva, 2019).

After the end of the ritual nestinar dance on fire, all spectators would start holding hands and dance together the Bulgarian folk dance horo. Nowadays the nestinar dance attracts spectators from all over the world and has become an exciting and stirring show (Baeva \& Toncheva, 2019). Its deep meaning and physical explanation however remain a scientific enigma.

\section{Enyovden (summer solstice)}

The day of the Northern Hemisphere's summer solstice, which falls between 20 and 24 June, is Enyovden or midsummer. In Christianity, this day is the nativity of St. John the Baptist. However, the Bulgarian tradition of celebrating Enyovden is much older and is associated with a young mythical hero connected to the power of the sun who brings fertility, health and happy marriage to young women (Baeva \& Toncheva, 2019). This day is of a unique transitional nature. In the folk tales, the sun stops for a short moment in the sky and slowly begins to "die" as the year transitions toward winter. On the cusp of Enyovden, the energy of the sun is the highest and gets transmitted onto the water, magic herbs, flowers and the morning dew. People wake up early in the morning to bathe in the rivers, lakes and springs or roll on the grass covered in dew. Enyovden is suitable for divinations and magic acts with symbolic characteristics (Karpodini-Dimitriadi et al., 2008). 
A traditional perception related to this day is the greater magical and healing powers herbs harvested on Enyovden receive. Women - older and younger, pick up 77.5 different herbs which cure the 77 different existing diseases according to Bulgarian folklore. The half herb is for the incurable disease and can be picked up only with your eyes closed (Baeva \& Toncheva, 2019). In addition to healing, these herbs also have magical powers to bring love or chase bad spirits away.

The Enyovden festivities are accompanied with fortune telling, uttering spells and blessings for health and success, ritual passage under the Enyov wreath of herbs - all features of nature in transition. It is a celebration that has deep roots associated with beliefs in the miraculous healing and loving power of herbs, in the life-giving force of water, and the sun cult rites for prosperity, health and a better future. In some places, a young 3-5-year-old girl is dressed like a bride with a red veil and is carried from house to house on the shoulders of four young women symbolising the sun's bride with whom the sun falls in love and steals away in the sky (Baeva \& Toncheva, 2019). All rituals, including the folk songs and dances, relate to marriage, fertility, health and disease prevention.

There are many more pagan festivities throughout the year which reflect the folk wisdom. For example, it is not allowed to work in the field or at home during the three hottest days in July (15 to 17 July). Those who break this rule will be punished by fire through lightening from the sky which will burn the land and their houses or will bring diseases with high temperature. The festivities for the remainder of the year similarly entertwine symbols from Christianity, such as the cross and different saints, with enigmatic paganistic traditions revering fertility, health and harvesting.

\section{COMMON FEATURES BETWEEN THE FOLK TRADITIONS AND FOOD SYMBOLISM}

All traditional rituals share similar connections to sustainability. Aimed at maintaining people's health, they emphasise the importance of food in terms of growing plants but also making eating a shared communal experience. The Bulgarian pagan traditions which have withstood the test of time are in no way opposed to Christianity. On the opposite, they have merged into the Christian beliefs reinforcing the power of the divine forces. On the other hand, they have and continue to shape Bulgarian culture supporting healthy eating and social habits. As a consequence, the traditional Bulgarian cuisine hides special symbolism and meaning related more to paganistic and less to Christian influences. For centuries, unwritten rites, ritual practices and prohibitions, divination and predictions, spells, incantations, blessings and prayers have guided the lifes of Bulgarians. These practices are complimented with the preparation of traditional Bulgarian food as part of the ritual complex performed. Specific ingredients and strict preparation methods are used and passed on from one generation to the next in the aim of preserving the traditional Bulgarian heritage.

The most common Bulgarian main cooked food is plant-based which has a much lower environmental impact on the planet (Raphaely \& Marinova, 2016). Moreover, the preparation of such meals is not a sign of poverty, but part of the tradition among Bulgarians to maintain good health for the people and the soils in the country. The symbolism of food is based on the ever-regenerating nature and includes: garlic to guard against evil forces, legumes representing fertility through their bulging during the cooking process, onions and nuts are used to guess and predict what the year ahead will be... Ritual bread is used in countless varieties, lavishly decorated with doughy birds, leaves, crosses, suns, circles etc. kneaded for manyfold reasons with the vital symbolism to bring health and happiness, home prosperity, to enhance fertility and the good harvest. The circle form of many of the breads epitomises the idea of the sun and the constant eternally reviving nature (Topalov \& Nikolaeva, 2006).

In pagan times and throughout the centuries, food preparation and consumption have been consistent with the seasonal calendar for fruits and vegetables, seeds, grains, cereals, nuts, beans and other legumes not only in everyday meals but also as core ritual food. If meat and other animal-based products are to be consumed, they are restricted to less than half of the days in a year. All internal 
animal organs, parts, cuts and bones are used with little wastage allowed. There is an acknowledgement of the fact that food requires great effort to be produced and people rely on weather conditions; hence they need to predict the signs of nature and perform rituals to increase fertility.

All specific traditional celebrations described here share many common features. First, they respect nature and its importance for human survival and the production of food. This is represented through the acknowledged power of the sun, the importance of rain and different seasons. Second, they see humans as being part of nature with no major boundaries drawn between the fertility of the soil and that of people. Third, it is believed that nature has healing capacity and all cures for people's diseases as manifested through medicinal herbs and fire. Fourth, all rituals involve people getting together dancing, singing and eating traditional Bulgarian food. This keeps the community spirit and health alive. In all celebrations, there is a part for men, women, young and old Bulgarians to play. Fifth, the origines of the rituals described here go to pagan times and although religion and development have affected or modernised some of their characteristics, they remain deeply rooted in the spiritual world of the Bulgarian ancestors with no or very limited commercialisation. They are explicit demonstrations of sustainability values and care for the land and other human beings.

\section{CONCLUSION}

The unification which layed the foundations of the Bulgarian state in the $9^{\text {th }}$ century seems to be continuing until present day as demonstrated through the surviving pagan traditions. Taking place in crucial periods of the year, such as the winter and summer solstice or the awakening of the earth in spring, these traditional Bulgarian festivals, carnivals and celebrations are an irrevocable part of the folk calendar and ritual system of a sustainable food culture. Building a link between folklore tradition and modern life in relation to the cultural heritage and cultural identity helps understand the nature of the place in terms of its past as well as its future. It is important to support and facilitate habits and traditions that encourage sustainable behabiour without compromising the quality of life in modern Bulgaria.

Food forms a major aspect of sustainability and is a significant contributor to climate change, particularly the overconsumption of animal-based products. Bulgarians have been practising fasting through abstaining from meat, fats, dairy, eggs and fish for most of the year or 200 days (Gaydurkov, 2014; Kostova et al., 2018) because of the respect they held for nature and the cyclical succession of seasons. Bread is commonly eaten, including made from rye and millet flours. Traditional meals and soups are based on beans, lentils, cabbage, mushrooms, wild plants like nettle, dock, sorrel, garlic, onion, leek, the "new crop" rice, peppers, tomatoes, potatoes, porridge, oatmeal, cornmeal for polenta, and other fruits and vegetables. The periods of lent imposed by the Bulgarian Orthodox Church are an example of the fusing between paganism and the Christian religion in ways that support sustainability and care for the health of the planet and its people.

The sustainability agenda which was highlighted in the $20^{\text {th }}$ century and is now continuing through the global Sustainable Development Goals, has long existed in Bulgaria and across the world through local spiritual, pagan, religious, ethnic, social and cultural practices. Their principles and underlying concepts have withstood the test of time and continue to respresent human wisdom and experience in dealing with the local natural environments. The sustainability challenges however are new in taking a global dimension through anthropogenic climate change, unprecedented land conversion of native vegetation areas for agricultural use, loss of biodiversity and diminishing social cohesion. These challenges require global thinking and local actions where folk culture can make a strong contribution.

Over time some traditional carnivals, festivals and celebrations have lost part of their previous potency. On the other hand, the interest in others is resurging. An example is the popular book by Rosemary De Meo (2016) describing Bulgarian folk traditions which has gained a lot of popularity and attracted a wide audience. The book refers to 11 folk commendments, the last of them being: "Respect everybody's faith, be it theirs or yours, as it is the most precious need and right of every person". 
The fact that these Bulgarian faith traditions continue to be alive across the country is extremely important and valuable. They are living artefacts of the Bulgarian spiritual heritage and quintessential ways of understanding and venerating nature. Many of the folklore traditions have firmly reestablished themselves as part of the present-day Bulgarian society bringing social cohesion, sustainability values and hope for the future in a place where people continue to be humble in respecting the divinity and power of nature. 


\section{REFERENCES}

Agency France Press (AFP). (2018). Bulgaria's rose surplus crushes petal prices. https://www.thephuketnews. com/bulgaria-rose-surplus-crushes-petal-prices-67350.php\#PGtLDaAGJCEqpFxP.97

Angelova, M. (2017). Kukeri, Bulgaria's Bizarre Festival of Monsters. https://theculturetrip.com/europe/bulgaria/ articles/kukeri-bulgarias-bizarre-festival-of-monsters/

Angelova, R. (1967). Les masques populaires bulgares. Schweizerisches Archiv für Volkskunde, 63(3-4), $226-239$.

Arnaudov, M. (1996). Essays on Bulgarian folklore (3rd ed., Vol. 2). Academic Publicating House Prof. Marin Drinov. (in Bulgarian)

Baeva, V., \& Toncheva, V. (2019). Big book: The Bulgarian celebrations and traditions. Pan. (in Bulgarian)

Beck, U. (1999). What is globalisation. Polity Press.

Bonye, Z. S. (2008). Harnessing Synergies: The Role of Traditional Institutions in Natural Resource Management in the Tallensi/Nabdam District, Upper East Region (Master's Thesis). University of Development Studies, Tamale, Ghana. https://www.codesria.org/spip.php?action=api_docrestreint\&arg=6638/0f91bd6f785db386e7 b32e0aac9eb386bdd2db27/pdf/m_bonye_samuel_z-2.pdf

Brown, R. (2018). Surreal pictures show Bulgaria's masked dancers warding off evil spirits. National Geographic. https://www.nationalgeographic.com/travel/destinations/europe/bulgaria/kukeri-survakari-unesco-intangiblecultural-heritage-photos/

Bulgarian Academy of Science. (2007). Bulgarian calendar holidays and rites. In Bulgarian Encyclopaedia. Publishing House Marin Drinov. (in Bulgarian)

Bulgarian National Television (BNT). (2019). Paganistic Bulgaria. https://www.bnt.bg/bg/a/ezicheskablgariya-13052019 (in Bulgarian)

Cameron, A. G. (2011). The last pagans of Rome. Oxford University Press.

Central Intelligence Agency (CIA). (2019). Europe: Bulgaria. The world factbook. https://www.cia.gov/library/ publications/the-world-factbook/geos/bu.html

Coker, C. (2002). Globalisation and insecurity in the Twenty-first Century: NATO and the management of risk. Routledge.

De Meo, R. (2016). God's master. Club 8 and Narichane EOOD. (in Bulgarian)

di Donato, J. (2018). What makes Bulgarian rose parfum so luxe. Culture Trip. https://theculturetrip.com/europe/ bulgaria/articles/what-makes-bulgarian-rose-parfum-so-luxe/

Gaydurkov, G. (2014). Human nutrition (8th ed.). Sanitas. (in Bulgarian)

Georgieva, I. (1987). Nestinari in Strandja: Cultural-historical heritage of Strandja-Sakar. Narodna mladej. (in Bulgarian)

Harriss-White, B. (Ed.). (2002). Globalisation and insecurity: Political, economic and physical challenges. Palgrave Macmillan.

Harvey, B. (2010). Paganism - Contemporary. In The encyclopedia of religion and nature. https:// www.oxfordreference.com/view/10.1093/acref/9780199754670.001.0001/acref-9780199754670-e659 ?rskey $=\mathrm{Uq} 4 \mathrm{ZiB} \&$ result $=9$

Karpodini-Dimitriadi, E., Karapidaki, L., Papageorgiou, F., Mazur, J., Topalov, K., \& Boneva, L. (2008). Rural heritage and collective identity: Building the sustainability of rural communities. CULT-RURAL Promotion of a Cultural Area Common to European Rural Communities "Culture 2000” Framework Programme in Support of Culture. Euracademy Association. http://cultrural.prismanet.gr/themedia/File/Synthesis_theme_3.pdf

Kaul, V. (2012). Globalisation and crisis of cultural identity. Journal of Research in International Business and Management, 2(13), 341-349. 
Kostova, S., Atanasov, B., \& Marinova, D. (2018). Consumption of animal products in Bulgaria: The case for change. In D. Bogueva, D. Marinova, \& T. Raphaely (Eds.), Handbook of research on social marketing and its influence on animal origin food product consumption (pp. 283-297). IGI Global. doi:10.4018/978-1-52254757-0.ch019

Lent, J. (2018). Commentary: What will it really take to avoid collapse? Environmental Health News. https:// www.ehn.org/capitalism-and-our-environmental-collapse-2521833465.html

Lozanova, V. (2007). Marta (Martenitsa). Encyclopedia of Ancient Thrace and Thracians. https://www.thracians. net/index.php?option=com_content\&task=view\&id=411\&Itemid=106 (in Bulgarian)

MacDermott, M. (1998). Bulgarian folk customs. Jessica Kingsley Publishers.

Marinov, D. (1994). People's faith and religious folk rites. Bulgarian Academy of Sciences. (in Bulgarian)

Nakashima, D., Prott, L., \& Bridgewater, P. (2000). Tapping into the world's wisdom. Unesco Sources, 125(JulyAugust). https://unesdoc.unesco.org/ark:/48223/pf0000120200

National Statistics Institute (NSI). (2010). Interview with Ivan Balev - director of the Demography and Social Statistics Directorate of NSI by Focus Agency. https://www.nsi.bg/bg/content/8526/интервю-на-иван-балевдиректор-на-дирекция-“демографска-и-социална-статистика”-на-нси (in Bulgarian)

Nova. (2018). Ethnologue: Bulgarians love celebrate pagan feasts. https://nova.bg/news/view/2018/02/14/207116/ етнолог-българите-обичаме-да-почитаме-езическите-празници (in Bulgarian)

O'Suvillan, D., \& Jackson, M. J. (2002). Festival tourism: A contributor to sustainable local economic development? Journal of Sustainable Tourism, 10(4), 325-342. doi:10.1080/09669580208667171

Oktyabrskaya, I., Okhotnikov, A., \& Chernykh, A. (2008). Holidays in the modern world: traditions and innovations. "Kamva-2007": traditional culture in the context of the ethno futuristic festival. Archaeology, Ethnology \& Anthropology of Eurasia, 33(1), 123-133. doi:10.1016/j.aeae.2008.04.004

Oswald Spring, Ú. (2019). Peace and sustainability in a globalised world. In Úrsula Oswald Spring: Pioneer on gender, peace, development, environment, food and water. Springer. doi:10.1007/978-3-319-94712-9_7

Panayotova, P. (2008). Trifon Zarezan (St. Trifon the Pruner), folk-wise. Balkan Folk. https://www.balkanfolk. com/news.php?id=94

Paskova, Y. (2018). Beautiful pictures from Europe's Valley of Roses: This source of national pride in Bulgaria's Balkan Mountains erupts in color every year. National Geographic. https://www.nationalgeographic.com/travel/ destinations/europe/bulgaria/things-to-do-rose-harvest-festival/

Petel.bg. (2016). On 21 May celebrate their name day... https://petel.bg/Na-21-may-imen-denpraznuvat----_157220 (in Bulgarian)

Raphaely, T., \& Marinova, D. (Eds.). (2016). Impact of meat consumption on health and environmental sustainability. IGI Global. doi:10.4018/978-1-4666-9553-5

Rose Festival Kazanlak. (2019). Bulgaria's Rose Valley and Rosa Damascena - the Bulgarian rose. https:// www.rosefestivalkazanlak.com/rosa-damascena-importance-bulgarian-rose-valley/

Rousseva, M. (2010). Continuity and creativity: The roots of contemporary Bulgarian art. http://writing.upenn. edu/wh/involved/series/artgallery/dancing_rousseva.pdf

Rupert, M. (2000). Ideologies of globalisation: Contending visions of a New World Order. Routledge.

Topalov, K., \& Nikolaeva, V. (2006). From symbolism to collective identity. Building the sustainability of rural communities. Theme 3, Cult Rural: Promotion of a Cultural Area Common to European Rural Communities. http://cultrural.prismanet.gr/themedia/File/\%20Reports/RUR_Izsledvane_KTopEN.pdf

Trud. (2016). Paganism resurects in Bulgaria. https://trud.bg/езичеството-възкръсва-в-българия/ (in Bulgarian)

United Nations Educational and Cultural Organisation (UNESCO). (2017). Cultural practices associated to the 1st of March: Bulgaria, North Macedonia, Republic of Moldova and Romania. https://ich.unesco.org/en/RL/ cultural-practices-associated-to-the-1st-of-march-01287 
Valchinova, G. (1999). "Znepolski praises”: Local religion and identity in Western Bulgaria. Prof. Marin Drinov Publishing House. (in Bulgarian)

Verma, M. K. (Ed.). (2019). Globalisation, environment and social justice: Perspectives, issues and concerns. Routledge.

\section{ENDNOTE}

The Bulgarian word "Кукери" is transcribed in English as "Kukeri” but the French transcription "Koukeri" is also used.

Diana Bogueva is a Centre Manager at the University of Sydney Centre for Advanced Food Enginomics and an Adjunct Postdoctoral Fellow at the Curtin University Sustainability Policy (CUSP) Institute. She is an interdisciplinary early career researcher focused on food sustainability, food innovations and consumer behaviour change.

Dora Marinova is originally from Bulgaria and then moved to Perth, Western Australia in 1991. She is a Professor of Sustainability at the Curtin University Sustainability Policy (CUSP) Institute. Dora has over 400 referred publications and has supervised $65 \mathrm{PhD}$ students to successful completion. She has served as a member of Australia's National Health and Medical Research Council's Panels on Centres of Research Excellence in Population Health and in Service Delivery. Her research interests cover innovation models, including the evolving global green system of innovation and the emerging area of sustainometrics. A distinctive area of her academic contribution is flexitarianism (or part-time vegetarianism) as a powerful concept to reduce the environmental impact of food, improve human health and generate business opportunities around plant-based proteins.

Vladislav Ivanov Todorov graduated from Sofia University, Faculty of Mathematics and Informatics, holds a Master Degree in Mathematics and a PhD from the Russian Academy of Management in Moscow, Russia. Since 1997 he has worked at the Department of Computer Sciences and Informatics, University of Forestry in Sofia, Bulgaria. Between 2003 and 2016 Vladislav was Deputy Dean and Dean of the University of Forestry's Faculty of Business Administration. His research interests cover information modeling of sustainable development, information theory, and IT application in business management. He teaches in the areas of econometrics, GIS and Management Information Systems. Vladislav has more than 60 publications, in which: 3 monographies published abroad in English; 6 university textbooks and electronic teaching courses author/co-author, as well as 46 scientific articles author/co-author. His publications have more than 100 citations in foreign languages publications in international refereed academic editions. Vladislav participates in 10 scientific projects, including 2 international projects, in editorial boards of 3 scientific journals with international participation. He is member of two international organizations of scientists; visiting academic at Curtin University, Perth, Australia, 2009-2012, and from 2016 to present. 